\title{
A simple method for the clinical determination of the mitotic activity of the human prostate in vitro
}

\author{
K. E. O. SENiUS, J. PIETIL ̈̈, I. ARVOLA ${ }^{1}$, AND P. TUOHIMAA \\ From the Institute of Biomedical Sciences, University of Tampere, 33520 Tampere 52, Finland
}

SYNOPSIS Patients with a hyperplastic prostate were studied for the epithelial mitotic activity of adenomatous tissue by the ${ }^{3} \mathrm{H}$-thymidine labelling method. A simple method in vitro was improved for biopsy samples. The mitotic activities obtained in vitro were compared with those obtained in vivo. The results show that the mitotic activity is not affected by the short incubation of the samples in Tyrode's balanced salt solution.

Radioautography is becoming valuable in the clinical determination of mitotic activity. The technique has been used in the evaluation of gastric malignancies (MacFee, Ackerman, and Wangensteen, 1966). However, the injection in vivo of radioactive thymidine into tissues may result in a variation because of vascularization. Carcinomas in particular are occasionally well vascularized and then the radioactive thymidine may be injected directly into a blood vessel without any penetration into the tissue. In this study, we have improved on a simple method for an in-vitro determination of mitotic activity, which can be applied to any human biopsy material.

\section{Materials and Methods}

\section{PATIENTS}

The patients were admitted for a clinical study and prostatectomy because of urination problems with a diagnosis of hyperplasia of the prostate. The age of the patients varied between 60 and 81 years.

\section{IN-VITRO LABELLING METHOD}

Three biopsy samples were taken with a Tru-Cut biopsy needle (Travenol Laboratories, Inc, Morton Grove, Ill, USA) or a Veenema-Gusberg prostatic biopsy punch (J Sklar Mfg Co, Inc, Long Island City, NY, USA) from the right lateral lobe of the prostate.

The samples were immediately (in one minute) incubated at $37^{\circ} \mathrm{C}$ in $4 \mathrm{ml}$ of Tyrode's balanced salt solution with $1 \mu \mathrm{Ci}$ per ml of tritiated thymidine (6-3 ${ }^{3}$-thymidine, specific activity $21 \mathrm{Ci}$ per mmole; Radiochemical Centre, Amersham, England) for ${ }^{1}$ Address: Tampere Central Hospital, SF-33520 Tampere, 52, Finland Received for publication 5 August, 1974.
30 minutes. The samples were fixed in $4 \%$ buffered formaldehyde $(0 \cdot 1 \mathrm{M}$ phosphate buffer, ph $7 \cdot 2)$ for 24 hours.

\section{IN-VIVO LABELLING METHOD}

Ten $\mu \mathrm{Ci}$ of tritiated thymidine per $0.5 \mathrm{ml}$ of and indigo carmine solution $(0.02 \mathrm{~g}$ of indigo carmine in a $5 \mathrm{ml}$ ampoule; Merck, Darmstadt, Germany) was injected into the left lateral lobe of the same prostate $6 \pm 1$ minutes before the prostatectomy. Three samples were taken from the blue injection site and the samples were fixed in a $4 \%$ buffered formaldehyde solution for $\mathbf{4 8}$ hours.

\section{RADIOAUTOGRAPHY}

Paraffin sections $(5 \mu \mathrm{m})$ were dipped in a nuclear emulsion (NTB-3, Kodak Co, Rochester, NY, USA) (Tuohimaa and Niemi, 1968). The slides were exposed for 14 days at $-20^{\circ} \mathrm{C}$. Radioautographs were developed in the Kodak-19 developer for two minutes and fixed in a rapid fixative. The sections were stained with Harris' haematoxylin-eosin.

The number of labelled cells per total cell population (labelling index) was counted from the epithelium under a Leitz-Wetzlar microscope with a magnification of 150 times. The labelling index was counted from three different sections for each of three samples from the patient. The number of counted cells for each prostate varied from 2500 to 20000 depending on the statistical significance.

\section{STATISTICS}

The statistical comparison of the results was made using the analysis of variance and the regression analysis. 


\section{Results}

The results are shown in the table. There was no statistically significant difference between any individual in vivo and in vitro labelling index values, and the mean value of the samples from nine patients was $0.24 \pm 0.04$ (SE) \% by both methods. Similarly, there was no difference in the grain density per labelled nucleus (fig, A and B).

If $y$ resembles the labelling index obtained in vitro and $x$ that obtained in vivo, the regression line calculated on the basis of our results is $y=0.90 \cdot x$ +0.02 . This line does not differ significantly from the theoretical line, $y=x$, and the correlation between the experimental values and the regression line is highly significant $(r=0.915 ; P<0.001)$.

\begin{tabular}{|c|c|c|}
\hline \multirow[t]{2}{*}{ Patient } & \multicolumn{2}{|c|}{ Labelling Index $(\%) \pm S E$} \\
\hline & In Vivo & In Vitro \\
\hline $\begin{array}{l}\text { E.H. } \\
\text { E.N. } \\
\text { J.M. } \\
\text { T.S. } \\
\text { A.S. } \\
\text { U.J. } \\
\text { A.L. } \\
\text { K.H. } \\
\text { L.L. }\end{array}$ & $\begin{array}{l}0.29 \pm 0.01 \\
0.24 \pm 0.03 \\
0.12 \pm 0.01 \\
0.41 \pm 0.08 \\
0.34 \pm 0.01 \\
0.10 \pm 0.01 \\
0.20 \pm 0.02 \\
0.35 \pm 0.02 \\
0.15 \pm 0.03\end{array}$ & $\begin{array}{l}0.28 \pm 0.04 \\
0.21 \pm 0.04 \\
0.17 \pm 0.01 \\
0.32 \pm 0.04 \\
0.35 \pm 0.02 \\
0.09 \pm 0.01 \\
0.20 \pm 0.02 \\
0.41 \pm 0.03 \\
0.12 \pm 0.01\end{array}$ \\
\hline Mean \pm SE & $0.24 \pm 0.04$ & $0.24 \pm 0.04$ \\
\hline
\end{tabular}

Table Individual labelling indices in vivo and in vitro of nine patients studied
Discussion

The results clearly demonstrate that it is possible to determine accurately in vitro the mitotic activity of human tissue. This indicates that the mitotic activity of the human prostate can persist at least for a few minutes (probably not as long as 30 minutes) after the biopsy. Thus complicated tissue culture methods are not required for a study of mitotic activity. On the other hand, it has been shown that longer cultivation of the prostate tissue in vitro may to a remarkable extent affect the mitotic activity (Simnett and Morley, 1967). This harmful effect of the culture process does not appear immediately, but makes it possible to use this simple system with different kinds of tissue, because in immediate experiments the nutrients of the tissues are not needed. Thus it may serve a wide-ranging purpose in prognostic-diagnostic studies of malignancies. It may be especially valuable to know the mitotic activity when the therapy for a malignant tissue is selected. Usually mitotic activity even in carcinomas is too low to be accurately determined by direct light microscopy, whereas the ${ }^{3} \mathrm{H}$-thymidine labelling makes the counting easier and, thus, indirectly also gives a better estimation of mitotic activity.

The labelling index of the epithelium of the present series of hyperplastic prostates is in the range of that of normal prostates (Faul and Rabes, 1972).

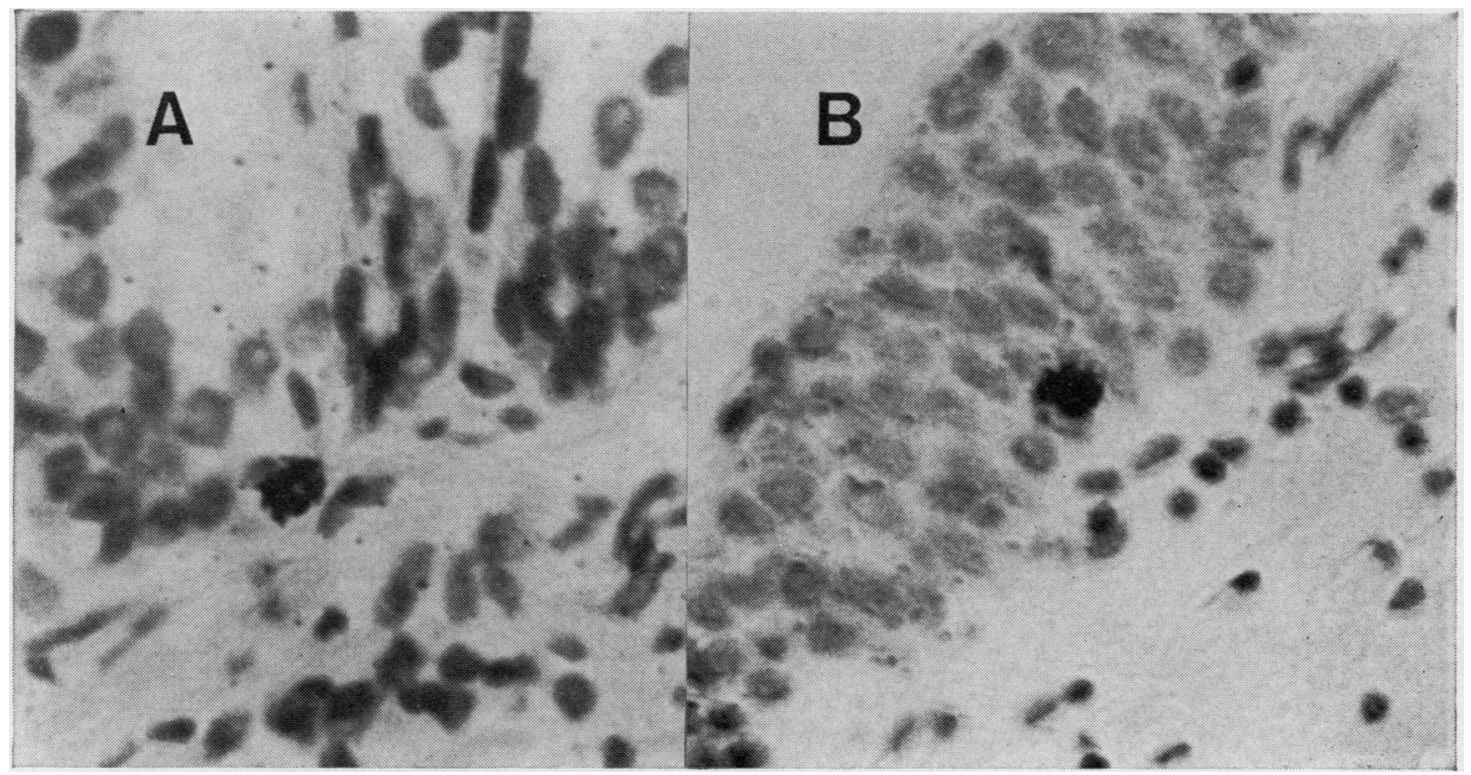

Fig The labelled nucleus in vivo (A) and in vitro (B). $\times 1000$. 
This supports the idea that prostatic hyperplasia is due to the growth of interstitial tissue. On the other hand, we also found a low labelling index in the interstitial tissue cells of hyperplastic prostates.

The authors are indebted to Miss Merja Helle for her technical assistance as well as to the nursing staff of the department of surgery in Tampere Central Hospital. This study was supported by a research grant from the University of Tampere, Finland.

\section{References}

Faul, P., and Rabes, H. (1972). Thymidin- ${ }^{3} \mathrm{H}$-autioradiograph an cytologischen Prostata-Punktaten des Menschen. Urologe, [A] 11, 295-299.

McFee, A., Ackerman, N., and Wangensteen, O. H. (1966). In vivo radioautography as an aid in the detection of gastric malignancy. Med. Biol., 16, 26-32.

Simnett, J. D., and Morley, A. R. (1967). Factors controlling growth of prostatic epithelium. A comparison of mitotic activity in mice of different ages in vivo and in organ culture. Exp. Cell Res., 46, 29-36.

Tuohimaa, P., and Niemi, M. (1968). The effect of testosterone on cell renewal and mitotic cycles in sex accessory glands of castrated mice. Acta endocr. (Kbh.), 58, 696-704. 